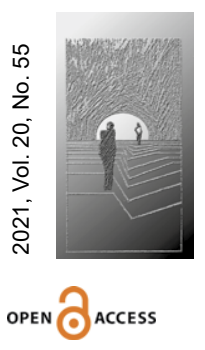

\title{
Rola dziadków w życiu dziecka z zaburzeniem ze spektrum autyzmu
}

\section{STRESZCZENIE}

CEL NAUKOWY: Celem artykułu jest próba znalezienia odpowiedzi na pytanie, jaka jest rola dziadków w rozwoju, wychowaniu oraz w opiece nad dzieckiem z ASD, a także jakie są sposoby wspierania dziadków w podejmowanych przez nich rolach.

PROBLEM I METODY BADAWCZE: Problem badawczy został sformułowany w formie pytań: 1) Jakie role podejmują dziadkowie dziecka z ASD? 2) Czy i jakiego wsparcia potrzebują dziadkowie w pełnieniu roli babci/dziadka? 3) W jaki sposób dziadkowie mogliby wspierać rozwój wnuka/ wnuczki z ASD? W pracy zastosowano metodę analizy literatury przedmiotu.

PROCES WYWODU: Punktem wyjścia artykułu jest wskazanie objawów zaburzenia ze spektrum autyzmu, następnie przegląd literatury dotyczącej roli dziadków w życiu dziecka. Następna cześć dotyczy przeglądu badań nad dziadkami dzieci z ASD. Ostatnia część dotyczy wskazania, w jaki sposób dziadkowie mogą uczestniczyć w życiu wnuka/wnuczki z ASD, w jaki sposób mogą wspierać jego rozwój, współuczestniczyć w wychowaniu i opiece.

WYNIKI ANALIZY NAUKOWEJ: Z przeprowadzonych analiz wynika przede wszystkim brak dostatecznej liczby badań i analiz dotyczących dziadków dziecka z ASD, a dalej wskazują one trudności w zrozumieniu zachowań i funkcjonowania dziecka z ASD przez dziadków oraz trudności w odgrywaniu roli babci/dziadka wnuka/wnuczki z ASD.

WNIOSKI, INNOWACJE, REKOMENDACJE: W świetle przeprowadzonych analiz należy zwrócić uwagę na potrzebę prowadzenia badań nad dziadkami dzieci z ASD, a także na podjęcie działań ukierunkowanych na wspieranie seniorów w odgrywaniu roli babci/dziadka dziecka z ASD.

\section{$\rightarrow$ SŁOWA KLUCZOWE: ZABURZENIA ZE SPEKTRUM AUTYZMU, DZIADKOWIE,} WSPARCIE 


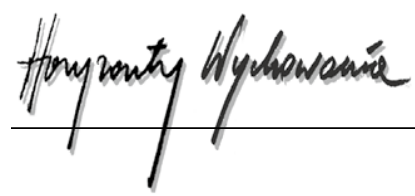

ABSTRACT

The Role of Grandparents in the Life of Children with Autism Spectrum Disorders

RESEARCH OBJECTIVE: The aim of this paper is an attempt to answer the questions what the role of grandparents is in the development, upbringing and care of a child with autism spectrum disorders and how to support grandparents in their roles.

THE RESEARCH PROBLEM AND METHODS: The research problem was formulated in the form of the following questions: 1) What roles do the grandparents of a child with ASD take? 2) What kind of support do they need in their role of a grandmother or a grandfather? 3) How could grandparents support the development of their grandchild with ASD? The study uses the method of document analysis-literature on the subject.

THE PROCESS OF ARGUMENTATION: The starting point of the research is to indicate the symptoms of autism spectrum disorder, followed by the review of the literature concerning the role of grandparents in the child life. The next section refers to the review of grandparents of children with ASD The last part relates to the ways the grandparents can participate in a life of their grandson / granddaughter with ASD, support their development and co-participate in their upbringing and care.

RESEARCH RESULTS: The conducted analyzes show, first of all, the lack of a sufficient amount of research and analyzes concerning the grandparents of a child with ASD, and then, indicate the difficulties in understanding the behavior and functioning of a child with ASD by grandparents and difficulties in performing the role of a grandmother / grandfather of a child with ASD.

CONCLUSIONS, INNOVATIONS AND RECOMMENDATIONS: In the light of the analyzes carried out, attention should be paid to the need for conducting research on grandparents of children with ASD, and undertaking activities aimed at supporting seniors in performing the roles of a grandmother/ grandfather of a child with ASD.

\section{$\rightarrow$ KEYWORDS: AUTISM SPECTRUM DISORDERS, GRANDPARENTS, SUPPORT}

\section{Wprowadzenie}

Diagnoza zaburzenia ze spektrum autyzmu w rodzinie jest sytuacją, która doprowadza do wielu zmian w funkcjonowaniu systemu rodzinnego. Zmiany dotyczą nie tylko obszaru odgrywania roli rodziców czy rodzeństwa, ale także roli dziadków w rodzinie. Niejednokrotnie zdarza się, że to właśnie dziadkowie są pierwszymi osobami, które zauważają nieprawidłowości w rozwoju wnuka/wnuczki i to oni podejmują działania skierowane na zdiagnozowanie dziecka. Bywa także tak, że diagnoza spada na nich niespodziewanie, a warunki dostosowania się do nowej sytuacji są wyjątkowo trudne. Warto przyjrzeć się sytuacji dziadków dzieci ASD, ich roli w rodzinie, a także zakresu otrzymywanego wsparcia. 


\section{Zaburzenie ze spektrum autyzmu}

Zaburzenie ze spektrum autyzmu (ASD) jest neurorozwojowym zaburzeniem, którego objawy obserwowane są często już w we wczesnym okresie rozwoju dziecka w dwóch sferach: 1) nieprawidłowości w interakcjach społecznych i komunikacji oraz 2) organicznych i powtarzalnych wzorcach zachowania i zainteresowania (APA, 2013). Szacuje się, że 1 na 59 (16,9 na 1000) dzieci w wieku szkolnym zostało zidentyfikowanych z ASD (Centers for Disease Control and Prevention, 2017). Trudności rozwojowe ujawniają się najczęściej w okresie wczesnego dzieciństwa, co jest podstawą budowania relacji społecznych i komunikacyjnych w rodzinie. Nasilenie objawów u każdej osoby może być różne, co wpływa na możliwości funkcjonowania w rodzinie, w grupie rówieśniczej czy w społeczeństwie.

\section{Rola dziadków w życiu dziecka}

Role dziadków są określane jako najważniejsze spośród ostatnich ról przypisanych człowiekowi w trakcie życia, które są związane z przynależnością do rodziny. Jak zauważa I. Namysłowska (2000), tak jak innych ról w rodzinie, tak i tej należy się nauczyć, aby być dobrą babcią/dobrym dziadkiem.

Rola seniorów (babci/dziadka) w rodzinie ulegała zmianie na przestrzeni wieków w związku z przemianami społeczno-kulturowymi, demograficznymi i ekonomicznymi.

Role te w rodzinach układają się w dwa wymiary: 1) opiekuńczo-wychowawczy i 2) doświadczenie i mądrość. W wymiarze opiekuńczo-wychowawczym babcie i dziadkowie stają się często niezmiernie ważnym ogniwem w procesie wychowania wnucząt. Rodzice podejmując pracę zawodową, angażując się w rozwój osobisty i karierę, rozwiązując codzienne problemy rodzinne i pozarodzinne, często mają mniej czasu dla własnych dzieci. Babcie i dziadkowie, szczególnie tacy, którzy nie są już aktywni zawodowo, mają więcej możliwości organizacji czasu swoim wnukom/wnuczkom. Rola ta niejednokrotnie stoi w opozycji do postawy, którą prezentuje średnie pokolenie, a mianowicie nieingerowania w relację rodzic - dziecko. Tak więc dziadkowie stają się często powiernikami wnucząt, stając w ich obronie, w ich sprawie i po ich stronie, kochając swoje wnuki miłością bezwarunkową, pełną, dojrzałą. W podejmowaniu roli opiekuńczo-wychowawczej nie zauważa się różnic pomiędzy kobietami i mężczyznami. Zarówno babcie, jak i dziadkowie deklarują pomoc swoim dzieciom w wychowywaniu wnuków. Dziadkowie odgrywają głównie role wychowawcy dla starszych dzieci w rodzinie, a także udzielają wsparcia finansowego i pomocy w cięższych pracach domowych, babcie natomiast są zarówno wychowawczyniami dla dzieci w różnym wieku, jak i opiekunkami dla najmłodszych w rodzinie, pomagają także w prowadzeniu gospodarstwa rodzinnego. Czas, jaki oferują swoim wnukom, nie dotyczy tylko opieki, ale także wspólnej aktywności, spędzania czasu na zabawie. Cierpliwość, zaanagażowanie, refleksje i dystans do zachowań wnuka/wnuczki są właściwościami, których często brakuje zapracowanym 


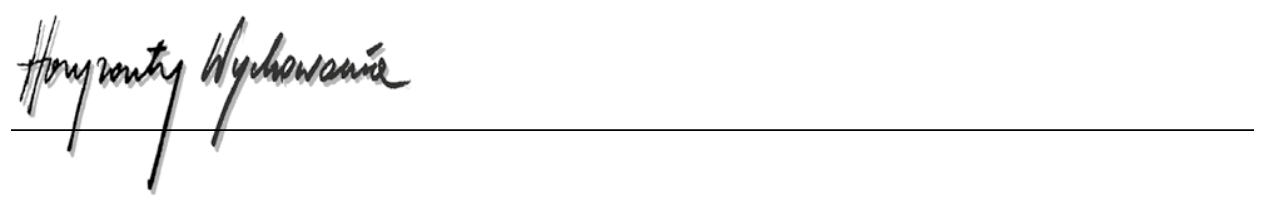

i przemęczonym rodzicom. Dziadkowie dają swoje zaangażowanie i zainteresowanie dzieciom w kontekście ich pasji, starają się je rozwijać, a niejednokrotnie są osobami, które zaprowadzają je na różne kółka zainteresowań, zajęcia pozalekcyjne i warsztaty. Dają swoją życzliwość, rozwagę, doświadczenie życiowe i odpowiedzialność także w zakresie bezpieczeństwa i w sytuacji choroby (Szpringer i Dąbrowska, 2011).

Babcie odgrywają role w scalaniu rodziny, mają częstszy kontakt z wnukami/wnuczkami, a także większy wpływ na nie, szczególnie na wnuczki. Zapewniają emocjonalne i instrumentalne warunki egzystencji rodziny, podejmując działania mające na celu utrzymania jej w całości (Appelt, 2007). Stoją na straży trwałości rodziny, zapewniają ochronę, bezpieczeństwo. Bywają także pomostem pomiędzy drugim a trzecim pokoleniem. Obniżają napięcie pojawiające się pomiędzy nimi, są negocjatorami w konfliktach.

Seniorzy w rodzinie są także inspiratorami zdobywania wiedzy, są źródłem ciągłości pokoleniowej, a także nauczycielami historii, tradycji, obyczajów (Bengston, 1985; Stelle i in., 2010).

Bycie babcią/dziadkiem to nie tylko czas „dawania”. Dla seniorów może to być także czas aktywizowania się do zdobywania nowych doświadczeń, odkrywania nowych umiejętności, które wcześniej nie były im znane. Zwiększają swoją adaptację do zmieniających się warunków życia, sytuacji społecznych czy pojawiających się przeciwności losu. Uczą się cierpliwości, akceptacji, tolerancji, zachowywania spokoju i równowagi. Budują także własną tożsamość (Steuden, 2011).

Pomimo wielu ról przypisywanym seniorom, związki dziadków z wnukami mogą być różne. Można wymienić tu trzy typy relacji: 1) zdystansowana - widywanie wnuków rzadko, niewielki kontakt i niewielki wpływ na życie najmłodszego pokolenia w rodzinie; 2) zaangażowana - podejmowanie się współwychowywania wnuków, zaangażowanie w opiekę; 3) towarzyska - tworzenie ciepłych relacji z wnukami, poświęcanie czasu, ale niepodejmowanie działań opiekuńczych i zastępowania rodziców (Bee, 2004).

\section{Rola dziadków dziecka z ASD}

Problemy rozwojowe dziecka z ASD są często trudne dla zrozumienia przez seniorów, a także utrudniają budowanie prawidłowej relacji z wnukiem/wnuczką. Według badań na doświadczenia dziadków związanych z wnukiem/wnuczką z ASD wpływ ma wiele czynników. Należą do nich: 1) cechy charakterystyczne dziadków (m.in. wiek, płeć, poziom wykształcenia, stan zdrowia), 2) cechy wnuka (wiek, nasilenie objawów), a także 3) relacje dziadków z rodzicami wnuka oraz wzorce funkcjonowania rodziny (Zakirova Engstrand $\mathrm{i}$ in., 2020).

Proces przeżywania i dochodzenia do akceptacji niepełnosprawności dziecka przebiega w podobny sposób jak u rodziców dziecka. W przypadku ASD sytuacja jest wyjątkowo trudna, ponieważ proces diagnozy często jest odwlekany w czasie przez samych rodziców bądź specjalistów, a możliwość poznania przyczyny stanu dziecka nadal bardzo mała. 
Z badań przeprowadzonych przez Interactive Autism Network wynika, że dziadkowie bywają pierwszymi osobami, które obserwują niepokojące objawy u swojego wnuka/ wnuczki. W grupie badanych dziadków 30\% seniorów zaobserwowało niepokojące objawy u swojego wnuka/wnuczki we wczesnym okresie rozwoju. Obserwacje te były dla nich wyjątkowo trudne. Dziadkowie wyrażali obawy, czy powinni informować o swoich spostrzeżeniach rodziców, przepełniał ich lęk przed zranieniem rodziców. Obawiali się, że nie są specjalistami w zakresie diagnozy i bywało, że zwlekali z werbalizowaniem swoich obserwacji, czekając, aż jakiś specjalista (np. w przedszkolu, lekarz pierwszego kontaktu) zauważy objawy nieprawidłowego rozwoju i poinformuje o tym rodziców. Łatwiej było wyrażać swoje opinie o rozwoju wnuka/wnuczki w sytuacji, kiedy rodzice także zauważali niepokojące zachowania i szukali potwierdzenia własnych obserwacji u innych członków rodziny (Interactive Autism Network, 2010). W procesie diagnozy dziadkowie czasami stają się osobami, które podejmują działania skierowane na swoje dzieci w celu wsparcia zaakceptowania diagnozy, inni stoją na stanowisku braku akceptacji rozpoznania, a jeszcze inni skupiają swoją całą energię na odnalezieniu przyczyny ASD i poszukiwaniu najnowszych metod leczenia. Niektóre badania wskazują także, że dziadkowie przeżywają okres żałoby (podobnie jak rodzice) po utracie oczekiwanego wnuka, pojawia się także poczucie winy związane z diagnozą (Hastings, 1997; Hillman, 2007).

Dziadkowie wnuka/wnuczki z ASD doświadczają w różny sposób swojej roli w rodzinie. Badania wskazują, że omawiana grupa babć i dziadków odczuwa potrzebę wspierania swoich dorosłych dzieci, którzy opiekują się swoimi dziećmi zASD. Badania J.K. Margetts, A. Le Couteur i S. Croom (2006) wykazały, że dziadkowie doświadczali takiej roli, jakby ponownie byli odpowiedzialni za swoje dzieci. Odczuwali podwójny ciężar opieki nad dwoma pokoleniami, ale deklarowali swoją bezgraniczną pomoc w każdej możliwej sytuacji, z jaką zwrócą się do nich ich dzieci. Seniorzy podkreślali także, że jest to dla nich bardzo trudna sytuacja, której towarzyszą silne emocje związane z przeżywaniem trudności wychowawczych i ciężaru opieki i wychowania, jakich doświadczają rodzice dziecka. U części dziadków podstawą podjęcia roli opiekuńczej nad wnukiem/wnuczką z ASD były obawy o stan zdrowia i życie własnego dziecka. Rodzice bowiem podejmowali ryzykowne zachowania mające na celu poradzenie sobie z zaistniałą sytuacją, takie jak nadużywanie alkoholu, substancji psychoaktywnych, leków. U części rodziców diagnozowano depresję, lęki. Niektóre małżeństwa rozpadały się ze względu na obecność niepełnosprawnego dziecka, co nasilało stres w rodzinie (Hillman i Anderson, 2019). Dziadkowie opiekę nad swoimi dorosłymi dziećmi w takich sytuacjach opisywali jako poczucie powrotu do własnego okresu rodzicielstwa nad małym dzieckiem, czuli się odpowiedzialni za własne dzieci, ale także za wnuki. Ich pomoc i opieka były często jedyną możliwością dalszego funkcjonowania rodziny. Identyfikacja ze swoimi dziećmi bywała tak silna, że seniorzy mieszali zaimki pierwszej i trzeciej osoby, używając ich zamiennie, łącząc własne doświadczenia z doświadczeniami ich dorosłych dzieci. Proces ten opisuje poziom zaangażowania dziadków przypominający ochronną wczesną więź między matką a dzieckiem. Jednak występuje ona nie tylko między dziadkami a ich 


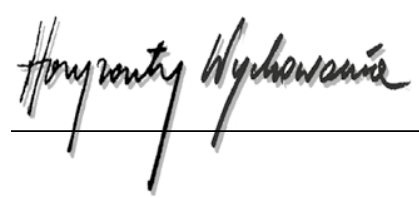

własnym dorosłym dzieckiem w czasie kryzysu, ale w różnym stopniu i między różnymi członkami rodziny, takimi jak dziadkowie i wnuki oraz dziadkowie i partnerzy ich dorosłego dziecka (Margetts i in., 2006, s. 570).

Pomoc, jaką oferują dziadkowie dziecka z ASD, dotyczy także wsparcia finansowego. Badania J. Hillman i współpracowników (2016) wykazały, że niektórzy dziadkowie pomagali opłacać terapeutyczne lub specjalne potrzeby swojego wnuka, biorąc pieniądze z funduszu emerytalnego lub banku. Niektórzy odkładali przejście na emeryturę, podjęli pracę po przejściu na emeryturę lub zmienili plany podróży, aby zdobyć dodatkowe pieniądze dla rodziny. Część dziadków podejmowała także opiekę wytchnieniową nad swoim wnukiem/wnuczką z ASD.

Pomoc dotyczy także wsparcia organizacyjnego związanego z dowożeniem wnuka/ wnuczki na zajęcia specjalistyczne, do placówki oświatowej, a także z organizacją czasu wolnego.

W opiece tej zwraca się uwagę na sytuację faworyzowania przez babcie i dziadków niepełnosprawnego wnuka/wnuczki, gdy wolno im więcej, mają więcej przywilejów w domu, mniej obowiązków. Seniorzy tłumaczą to faktem, że trudniej im wyjaśnić pewne aspekty dziecku bądź jest im żal sytuacji, w jakiej znajduje się wnuk/wnuczka z ASD (Margetts i in., 2006).

Opieka nad niepełnosprawnym wnukiem u seniorów może także doprowadzać do gromadzenia się czynników stresogennych. Stresory te obejmują problemy behawioralne, trudności w komunikacji, izolację społeczną i stygmatyzację, trudności w uzyskaniu i wdrożeniu leczenia, współistniejące problemy zdrowotne, problemy z utrzymaniem zatrudnienia, obciążenia finansowe i niejasne rokowania. U części dziadków podejmujących współopiekę nad wnukiem/wnuczką z ASD powodowało to pogarszanie się wyników zdrowotnych, bywało, że pojawiała się depresja (Hillman, 2007, s. 514; Hillman i Anderson, 2019).

W opiece nad niepełnosprawnym wnukiem należy także podkreślić fakt samodzielnego wychowywania przez dziadków wnuka/wnuczki z ASD. W Polsce trudno o dane dotyczące tej problematyki. Amerykańskie wyniki badań podejmujące ten temat wskazują, że dziadkowie negatywnie wypowiadają się o systemie prawnym, który utrudniał bądź nie wspierał podjęcia opieki nad niepełnosprawnym wnukiem/wnuczką, a ci dziadkowie, którzy sprawują pełnoprawną opiekę nad wnukiem/wnuczką z ASD, podkreślają, że mają ogromne trudności w kontakcie ze specjalistami, nauczycielami, którzy nie zawsze podążają za tym, co seniorzy wiedzą o dziecku i o jego codziennych rutynach, dających poczucie bezpieczeństwa, sposobach reagowania na zachowania. Wskazują także na problem z dostępem do specjalistycznych usług, które zapewnią wsparcie im i wnukowi/wnuczce, i niedostateczną wiedzę na temat zaburzenia. Równocześnie w opiece tej zauważają trudności w zrozumieniu zachowań dziecka, brak własnych umiejętności reagowania na zachowania agresywne, autoagresywne, destrukcyjne, stymulacyjne, zauważają, że potrzebują wskazówek, nowych rozwiązań na zmieniające się zachowania dziecka. Obciążeniem są także nakłady finansowe na oddziaływania terapeutyczne, specjalistyczne żywienie, pomoce terapeutyczne, które w dużej mierze 
nie są finansowane z funduszy państwowych. Dziadkowie, którzy nie sprawują prawnej opieki nad swoim niepełnosprawnym wnukiem, podobnie jak dziadkowie sprawujący pełną opiekę, zwracają uwagę na brak dostatecznej wiedzy na temat zaburzenia oraz problem z kontaktem ze specjalistami, którzy ze względu na brak sprawowania prawnej opieki nad dzieckiem nie udzielają informacji na temat jego zdrowia i funkcjonowania (Hillman i Anderson, 2019).

W opiece nad wnuczętami z ASD seniorzy doświadczają także pozytywnych emocji i przeżyć. Dotyczy to odczuwania miłości bezwarunkowej do swojego wnuka/wnuczki, czerpania radości ze spędzania czasu z nim, poczucia ważności roli, jaką podejmują oraz wdzięczności od swojego dziecka. Seniorzy cieszą się także postępami w rozwoju dziecka, umiejętnościami, które zdobywa, a także zmniejszającą się liczbą zachowań problemowych. Czerpią przyjemność ze wspólnych zabaw, wspólnej aktywności, a także z podejmowania czynności pielęgnacyjnych. Czują się potrzebni i doceniani przez swoje dzieci. Dają dużo ciepła wnukom, cierpliwości, zaangażowania w ich aktywności. Patrzą często na dziecko bez stereotypów i uprzedzeń, nie oceniają, nie pośpieszają. Często po prostu są przy wnuku/wnuczce.

Należy podkreślić, że tak jak w przypadku odgrywania roli babci/dziadka dziecka pełnosprawnego, tak i w przypadku wnuka/wnuczki z ASD nie każdy senior chce podejmować rolę opiekuńczą i wspierającą. Badania, w których przeanalizowano doświadczenia rodziców i dziadków, stwierdzono, że brak wsparcia z ich strony może nie być związany z niepełnosprawnością dziecka, ale raczej z historią relacji w rodzinie (Mirfin-Veitch i in., 1997).

\section{Implikacje praktyczne}

Podejmując rozważania nad wdrożeniem wspierania dziadków wnuków z ASD, należy podkreślić, że powinno ono obejmować kilka obszarów.

Pierwszym z nich jest edukowanie seniorów na temat autyzmu. Istotne jest wyposażenie dziadków w wiedzę na temat objawów, przyczyn, procesu diagnostycznego. Zrozumienie zachowań dziecka jest niezmiernie ważne w aspekcie przyszłej opieki nad dzieckiem. Dobrym rozwiązaniem byłoby włączanie chętnych do tego dziadków do procesu diagnostycznego, co ma szansę dać im odpowiedź na wiele pytań, które trudno zadać rodzicom.

Ponadto ważne jest opisanie metod terapeutycznych i sposobów oddziaływań medycznych, ich celów, zależności, możliwości rozwoju, ale także konsekwencji negatywnych braku podejmowania terapii. Konieczne jest zaprezentowanie dziadkom sposobów radzenia sobie w sytuacjach trudnych, takich jak agresja, autoagresja, zachowania destrukcyjne, stymulacyjne czy rutynowe. Sama wiedza jest jednak niewystarczająca. Ważne, aby dziadkowie zostali wyposażeni w praktyczne umiejętności w tym zakresie, co można wdrażać w ramach działania organizacji pozarządowych skierowanych na wspieranie rodzin osób z ASD, poradni psychologiczno-pedagogicznych, miejskich 


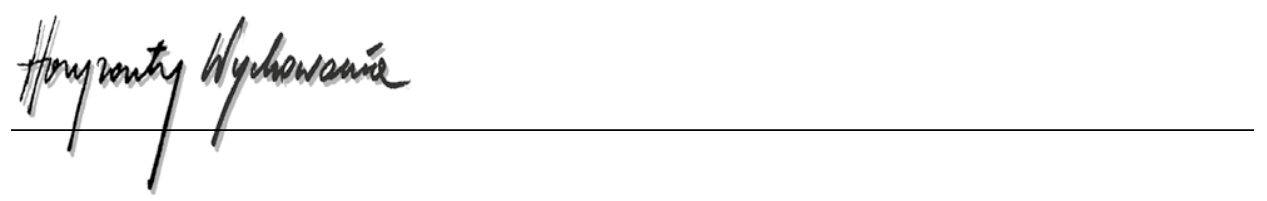

ośrodków wspierania rodziny czy placówek edukacyjnych, np. w formie warsztatów dla babć i dziadków.

Powinni oni być także wyposażeni w wiedzę i umiejętności dotyczące sposobów komunikowania się z niepełnosprawnym wnukiem/wnuczką w warunkach korzystania z systemów alternatywnych i wspomaganych metod komunikacji, np. w formie książki komunikacyjnej czy w formie elektronicznego oprogramowania. Badania wskazują, że dziadkowie w momencie wskazania im możliwości różnych systemów oprogramowania elektronicznego, które mają wspierać rozwój dziecka z ASD w szeroko rozumianym znaczeniu, np. komunikacji, edukacji, interakcji z rówieśnikami czy z dziadkami, pozytywnie oceniają takie działania (Wright i in., 2012).

Drugim obszarem wspierania dziadków wnuka/wnuczki z ASD jest wskazanie możliwości rozwiązywania konfliktów komunikacyjnych pomiędzy nimi a rodzicami dziecka. Zbudowanie prawidłowej komunikacji, która nastawiona jest na wskazanie potrzeb, możliwości, a także ograniczeń każdej ze stron ma szansę zwiększyć chęci podejmowania opieki i działań wspierających przez seniorów nad najmłodszym pokoleniem. Wydaje się również, że otwarta, kierowana komunikacja między rodzicami a dziadkami w celu wzajemnego zdefiniowania obowiązków i ról dziadków byłaby niezmiernie pożądana. Zmniejsza to ilość konfliktów i nieporozumień. Rodzice jak i dziadkowie powinni jasno określić swoje oczekiwania co do pełnionych funkcji w rodzinie (Strom i Strom, 2000).

Kolejny obszar to wsparcie instytucjonalne, które w dużej mierze dotyczy placówek edukacyjnych. W obszarze tym konieczne jest wdrażanie dziadków do procesu terapeutycznego wnuka/wnuczki z ASD. Zadaniem babci/dziadka nie ma być podejmowanie terapii, ale orientowanie się w zasadach panujących w procesie terapeutycznym i edukacyjnym. Niezmiernie istotne jest bowiem przestrzeganie wspólnych zasad w stosunku do dziecka z ASD, uspójnione reagowanie na różne zachowania i uspójnione wymagania w stosunku do dziecka. Instytucjonalne wsparcie dotyczy także informowania o placówkach wsparcia społecznego, które udzielają pomocy w wielu socjalnych aspektach, takich jak wsparcie materialne czy opiekuńcze. Szczególnie ważne jest to dla dziadków, którzy sprawują samodzielnie opiekę nad wnukiem/wnuczkiem (są prawnym opiekunem).

Obszarem działań jest tu także wskazanie możliwości spędzania czasu wolnego z dzieckiem z ASD, organizacji zabaw i wspólnych aktywności, tak aby były one przyjemne dla dziecka, a nie ciążyły seniorom. Wspólny czas z dzieckiem z ASD ma dawać także możliwość poznawania mocnych stron dziecka, umiejętności, zainteresowań czy pasji, które mogą zbliżać seniorów do najmłodszego pokolenia.

Dziadkowie mają także możliwość zrzeszania się w różnych organizacjach, mają możliwość dołączania do różnych grup wsparcia, które oferuje Internet. Warto podjąć działania, które motywują do poszukiwania takich miejsc. Czasami pozwolą one na podjęcie działań rzeczniczych. Działania rzecznicze mogą przynieść korzyści dziadkom, którzy uważają, że ich rola jest ograniczona z powodu problemów geograficznych lub zdrowotnych, które uniemożliwiają lub ograniczają bezpośredni kontakt z dziećmi z ASD lub ich rodzicami (Hillman, 2007, s. 523). 
Warto także wspomnieć, że poszerzanie wiedzy społeczeństwa na temat autyzmu może przynieść wiele korzyści związanych z jego wczesnym wykrywaniem. Dziadkowie są bowiem osobami, które mogą obserwować nieprawidłowy rozwój dziecka, a przez brak wiedzy nie komunikować o tym rodzicom. Wczesne wykrywanie ma z kolei niezmiernie istotne znaczenie w podejmowaniu bezzwłocznych oddziaływań w stosunku do dziecka (Buchnat i Wojciechowska, 2019).

Dziadkowie dzieci z ASD podejmują role bycia babcią/dziadkiem w dwojaki sposób. Najpierw w formie oczekiwań - chcą być dziadkami zdrowego dziecka, a potem życie weryfikuje tę rolę. Podejmują próby dostosowania się nowej sytuacji, adaptują swoją wiedzę i umiejętności do tego, czego nauczyło ich życie. Dziadkowie mają swoją intuicję. Warto jej zaufać, ale wspierać w tym, aby umieli pozostać babcią i dziadkiem. Po prostu... babcią i dziadkiem.

\section{BIBLIOGRAFIA}

APA. (2013). Diagnostic and statistical manual of mental disorders (wyd. 5). American Psychiatric Publishing.

Appelt, K. (2007). Współcześni dziadkowie i ich znaczenie dla rozwoju wnuków. W: A. Brzezińska, K. Ober-Łopatka, R. Stec i K. Ziółkowska (red.), Szanse rozwoju w okresie późnej dorosłości. Wydawnictwo Fundacji Humaniora.

Bee, H. (2004). Psychologia rozwoju człowieka (A. Wojciechowski, tłum.). Zysk i S-ka.

Bengston, V.L. (1985). Diversity and symbolism in grandparent roles. W: V.L. Bengtson i J.F. Robertson (red.), Grandparenthood (s. 11-26). Sage.

Buchnat, M. i Wojciechowska, A. (2019). Sytuacja wczesnej edukacji i opieki nad małym dzieckiem o nieprawidłowym rozwoju w Polsce - jej znaczenie i bariery. Interdyscyplinarne Konteksty Pedagogiki Specjalnej, 24, 71-87.

Centers for Disease Control and Prevention. (2017). Design and Operation of the National Survey of Children's Health, 2011-2012. Vital Health Stat, 1(59). National Center for Health Statistics.

Hastings, R.P. (1997). Grandparents of children with disabilities: A review. International Journal of Disability, Development, and Education, 44, 329-340.

Hillman, J. (2007). Grandparents of children with autism: a review with recommendations for education, practice, and policy. Educational Gerontology, 33, 513-527.

Hillman, J.L. i Anderson, C.M. (2019). It's a battle and a blessing: The experience and needs of custodial grandparents of children with Autism Spectrum Disorder. Journal of Autism and Developmental Disorders, 49, 260-269.

Hillman, J., Marvin, A. i Anderson, C. (2016). The experience and contributions of grandparents of children with autism spectrum disorders. Journal of Intergenerational Relationships, 14(2), 76-92.

Interactive Autism Network. (2010). Grandparents of children with ASD. https://www.iancommunity. org/cs/ian_research_reports/ian_research_report_apr_2010

Margetts, J.K., Le Couteur, A. i Croom, S. (2006), Families in a state of flux: the experience of grandparents in autism spectrum disorder. Child: Care, Health and Development, 32(5), 565-574.

Mirfin-Veitch, B., Bray, A. i Watson, M. (1997). 'We're just that sort of family'. Intergenerational relationships in families including children with disabilities. Family Relations, 46, 305-311.

Namysłowska, I. (2000). Terapia rodzin. Instytut Psychiatrii i Neurologii. 


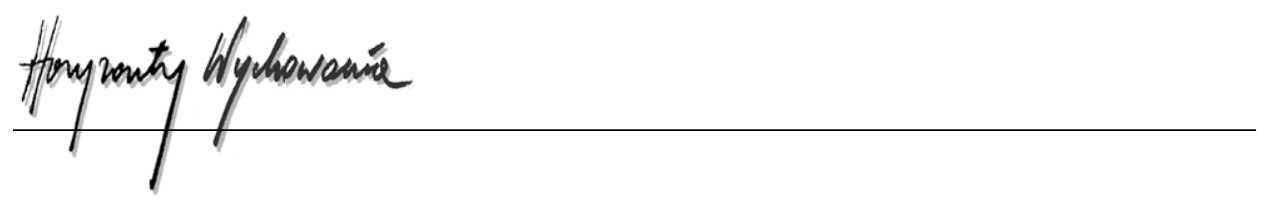

Stelle, Ch., Fruhauf, Ch.A., Orel, N. i Landry-Meyer, L., (2010), Grandparenting in the 21st century: Issues of diversity in grandparent-grandchild relationships. Journal of Gerontological Social Work, 53(8), 682-701.

Steuden, S. (2011). Psychologia starzenia się i starości. Wydawnictwo Naukowe PWN.

Strom, R.D. i Strom, S.K. (2000). Intergenerational learning and family harmony. Educational Gerontology, 26, 261-283.

Szpringer, M. i Dąbrowska, A. (2011). Misja dziadków w rodzinach XXI wieku: nowe role, wyzwania, oczekiwania. Studia nad Rodziną, 15(28-29), s. 247-254.

Wright, S.D., D'Astous, V., Wright, Ch. i Diener M. (2012). Grandparents of grandchildren with Autism Spectrum Disorders (ASD): Strengthening relationships through technology activities. The International Journal of Aging and Human Development, 75(2), 169-184.

Zakirova Engstrand, R., Roll-Pettersson, L., Westling Allodi, M. i Hirvikoski, T. (2020). Needs of grandparents of preschool-aged children with ASD in Sweden. Journal of Autism and Developmental Disorders, 50(1), 1941-1957.

\section{Copyright and License}

This article is published under the terms of the Creative Commons Attribution - NoDerivs (CC BY- ND 4.0) License http://creativecommons.org/licenses/by-nd/4.0/ 